DOI 10.31558/2307-2318.2019.3.13

UDC 336.73

Volkova N., PhD, associate Professor, Vasyl’ Stus Donetsk National University

Zolotar A., graduate student Vasyl' Stus Donetsk National University

\title{
CREDIT RISK MANAGEMENT
}

In the article it is investigated the credit risk management. The economic and legal principles of credit risk management of the bank, which are interpreted as risks of occurrence of losses in the bank by debtor as a result of failure, untimely or incomplete execution of financial obligations to the bank according to the terms of the contract, have been clarified. The effectiveness of managing the credit activity of banks depends on a competent credit management system has been proved. Based on the analysis of credit activity of domestic banks for 2015-2018, the negative tendency of their main indicators, which worsens the overall economic situation of our country, has been concluded. Possibilities of managing bank risks by using marketing and management tools aimed at strengthening the financial stability of banks have been identified. The directions of improving the credit risk management of banks have been aimed at improving the efficiency of the credit risk management system to minimize losses by using the method of limitation.

Keywords: credit actions, management methods, self-insurance, loan portfolio profitability, limitation, results of activity.

\section{Волкова Н.І., Золотар А.К.}

\section{УПРАВЛІННЯ КРЕДИТНИМИ РИЗИКАМИ}

Досліджено управління кредитними ризиками. З'ясовано економіко-правові засади управління кредитними ризиками банку, що трактуються, як ризики виникнення у банку збитків в результаті невиконання, несвоєчасного або неповного виконання боржником фінансових зобов'язань перед банком відповідно до умов договору. Доведено, що ефективність управління кредитною діяльністю банків залежить від грамотної системи кредитного менеджменту. На основі аналізу кредитної діяльності вітчизняних банків за 2015-2018 роки зроблено висновок щодо негативної тенденції їх основних показників, що погіршує загальну економічну ситуацію нашої країни. Виявлено можливості управління банківськими ризиками шляхом використання інструментів маркетингу та менеджменту, направлені на зміцнення фінансової стійкості банків. Аргументовано напрями удосконалення управління кредитними ризиками банків, які спрямовані на підвищення ефективності системи управління кредитними ризиками для мінімізації збитків за допомогою використання методу лімітування.

Ключові слова: кредитні ризики, методи управління, самострахування, дохідність кредитного портфелю, лімітування, результати діяльності.

\section{Волкова Н.И., Золотарь А.К. УПРАВЛЕНИЕ КРЕДИТНЫМИ РИСКАМИ}

Исследовано управление кредитными рисками, а так же экономико-правовые основы управления кредитными рисками банка. С точки зрения авторов, кредитные риски трактуются как риски возникновения в банке убытков в результате невыполнения, несвоевременного или неполного выполнения должником финансовых обязательств перед банком в соответствии с условиями договора. Доказано, что эффективность управления кредитной деятельностью банков зависит от грамотной системы кредитного менеджмента. На основе анализа кредитной деятельности 
отечественных банков за 2015-2018 годы сделан вывод о негативной тенденции их основных показателей, что ухудшает общую экономическую ситуацию в нашей страны. Обоснованы направления совершенствования управления кредитными рисками банков, способствующие минимизации убытков посредством использования метода лимитирования.

Ключевые слова: кредитные риски, методы управления, самострахование, доходность кредитного портфеля, лимитирование, результаты деятельности.

Problem statement. The historical changes that took place in the banking activities of the American organization around the world at the end of 20 century - the deregulation and globalization of banking activities, the increasing competition, implementation of new informational technologies, financial innovations and banking services, improvement of forms of customer service - lead to the increasing of the level of financial risks that influence on banking activities results. The high importance of banks participation in the development of effective economic of the country strengthens understanding of the bank community, that risk management become a decisive factor in the increasing and support of competitiveness of each bank.

Analysis of recent research and publications. Many studies of domestic scientists, such as: N. Tarasenko, V. Vitlinsky, O. Tereshchenko, V. Galasyuk, A. Moroz, are devoted to the research in the banking sphere. It is noteworthy to note the achievements of scientists who have researched credit risk in particular, A.A. Epifanov, TA Vasilyeva, SM Kozmenko and others.

Currently, credit risks in the structure of financial risks of banks have a decisive influence on their activity results. In Ukraine, the real level of bank credit risks in absolute terms tends to increase, which is caused, first of all, by the expansion of lending to enterprises and organizations with low creditworthiness, as well as high concentration of credit risks in weak industries and individual enterprises.

At the same time, the insufficient level of credit risk analysis and assessment, as well as the lack of compliance with international requirements in this field, are currently characteristic of most Ukrainian banks.

In connection with the above, the importance of banks' systematization of methods of minimizing credit risks is increasing; a sound choice of measures to prevent the occurrence of risks at the level of individual loans and loan portfolios; introduction of new techniques of protection against negative consequences of occurrence of risks in the banking systems of credit risk management.

The purpose of the work is to solve a set of theoretical and practical problems of credit risk management of banks and to develop directions for solving raised problems.

Research results. In the research were used the following methods: theoretical generalization, analysis and synthesis - to study out and clarify the essence of concepts; methods of statistical analysis - to study the status of the loan portfolio and the risks of the current bank; systematic method - to substantiate recommendations for improving the effectiveness of credit risk management; methods of economic analysis, synthesis, comparison, analogy - to evaluate the values of the studied indicators; graphical method - for visualization of statistical material and schematic representation of a number of theoretical and practical provisions of the research.

The informational base of the research occupied official materials of the National Bank of Ukraine, indicators of PJSC JSB "Ukrgasbank" activity, materials of scientific conferences, Internet sources, results of own calculations. 
Priority activities of modern Ukrainian banks have been and are lending operations, banks receive their main income from lending. In the Law of Ukraine "On Banks and Banking" a bank loan is a bank's obligation to provide a certain amount of money" [1, Art. 2]. Credit transactions, are the main source of income for banks, and for debtors - the opportunity to obtain the necessary funds. Loans are the most profitable bank assets. Therefore, they are the most risky in the bank's operations and can lead to significant financial losses. NBU defines bank risk as "... the existing or potential risk to the proceeds and capital arising from the failure of the party, that has taken responsibility to execute the conditions of any financial agreement with the bank or otherwise fulfill the obligations assumed. "[2].

This work investigates credit risk, which is a key risk in the banking risk management system. We find out that quite often the essence of credit risk is replaced by the cause of its occurrence, that is, the interpretation is carried out in accordance with the circumstances and factors that lead to bank losses. This concept is identified with uncertainty, the possibility of incurring losses, not receiving the planned income. Some experts consider credit risk the risk of default and interest on it [2-4]. In doing so, it draws attention to the tautological nature of such an appeal and, given the widespread approach to treating risk as a possibility of loss, focuses on the negative, undesirable result of its manifestation. However, from a practical point of view, the focus should be on profitability, since in carrying out a particular transaction, especially a credit, the entity making the decision to implement it aims to make a profit and not to avoid losses.

The approach to the essence of credit risk as a probability of default or contractual terms [5] also narrows this notion, since it emphasizes the possible negative result, which is only one of the possible forms of its manifestation. However, the risk is always uncertainty as a result of an action or decision, so it is impossible to determine the consequences of its implementation in advance. In this regard, some scholars associate credit risk with uncertainty or lack of information. We agree with the statement that if the result is unknown in advance, it is difficult to predict in uncertainty what the impact of credit risk - negative, positive or zero will have. However, not only incompleteness of information but also peculiarities of the bank's credit policy, quality of credit risk management and so on affect the possibility of credit risk. With respect to other definitions, we agree to some extent with particular positions, in particular the fact that credit risk may arise due to the realization of a certain decision under the conditions of choosing from the available alternatives [6]; influence on credit risk of external and internal factors [7].

From our point of view, creating credit reserves is not a way to minimize risks. By creating reserves, banks assume the risk and set in advance the magnitude of the possible losses in order to have a source of write-off of the claim or part of it on the balance sheet in case of realization of this risk. The creation of provisions for possible losses can in no way affect the probability of fulfillment of obligations of debtors and accordingly does not reduce credit risks, does not affect the amount of possible losses.

Nowadays only the largest banks have all the resources they need to build objective credit risk assessment systems. Small and medium-sized banks do not have the necessary amount of statistical information on defaults and staff of adequate level and experience. In our opinion, in future, the solution to this problem in implementing the rating system for all participants of the banking system of Ukraine should become widespread use of outsourcing and consulting in this field.

Thus, credit risk minimization involves minimizing credit risk for individual liabilities, portfolio types, and the bank as a whole. At the same time, the so-called level of risk appetite, 
which each bank sets independently, is of decisive importance when choosing a credit risk management strategy.

It should be noted that the NBU order № 351 of June 30, 2016 [8] approved the Regulation on determining the size of credit risk by active banking operations by banks of Ukraine, the purpose of which is to provide a full and timely assessment of the amount of credit risk by banks, which will facilitate the correct calculation of their capital and, in ultimately, will strengthen the financial soundness of the banking sector. The regulation enhances approaches to the assessment of expected credit risk losses (based on Basel Banking Guidelines), compatible with IFRS 9 (Financial Instruments), which also requires the assessment of expected losses on financial instruments and has been implemented internationally since 01.01.2018. The special feature of № 351 is the combination of clear detailed rules and general principles of credit risk assessment, which provides for the use of sound judgment of both the bank and the regulator. As a result, banks will not be able to recognize the poor quality of assets, invoking formal rules.

To calculate the value of expected losses, the provision provides using the recommended formula by the Basel Committee on Banking Supervision that uses three components: the probability of debtor default (PD), the loss given default (LGD), and the exposure at default (EAD). The approaches prescribed by the provision, taking into account the NBU's findings on the practice of credit risk assessment by banks, including the results of the diagnostic examination of banks [9].

Therefore, credit risk is the existing or potential risk to the proceeds and capital arising from the inability of the party that has committed to fulfill the terms of any financial agreement with the bank or otherwise to discharge the obligations. Credit risk can be triggered by: the debtor's inability to generate adequate future cash flow due to unforeseen adverse changes in the business, economic and political environment in which the debtor operates.

We will provide information on loan activity of the banking system of Ukraine in the context of risk management during the last 4 years. It should be noted that since 2014 the economic situation in the country has deteriorated significantly. There was a sharp decline in production of all major economic activities except agriculture. There was an increase in inflationary pressures on the economy, which was accompanied by falling of real incomes of population and respectively decreases in its purchasing power [10].

The share of bank loans in GDP as of 1 January 2019 in comparison to the previous year have decreased by $3.5 \%$, which is an indirect sign of a decrease in the revitalization of credit investments of commercial banks in the direction of credit support of entrepreneurship (see Table 1).

Minor changes of the direction of increase are seen in the intensification of the activity of commercial banks of Ukraine in lending to economic entities. Thus, during 2016-2017, the share of credit investments increased, and in January 1, 2018 compared to the same period last year decreased by $0.9 \%$ and in January 1, 2019 its share is $82.1 \%$ of all granted loans. The information also indicates a weakening of lending by commercial banks to individuals, which should not be explicitly regarded as an exceptionally positive phenomenon, since the decline in credit growth does not meet the strategic objectives of stimulating economic growth. The share of loans to individuals in GDP decreases every year and in 01.01 .2019 is $5.5 \%$.

The effectiveness of bank lending depends on competent credit management system, which provides such an organization of the lending process, which systematically takes into account all the factors that affect the lending process within the modern scientific concept of banking management [12] 
In order to ensure the organization of effective lending activities, commercial banks develop their own internal credit policy and implement practical mechanisms for its implementation. That is why one of the most important tasks of credit management is the formation and analysis of credit portfolio of a commercial bank [13].

Table 1

Share of bank loans in GDP of Ukraine, mln. UAH [11]

\begin{tabular}{|c|c|c|c|c|}
\hline \multirow{2}{*}{ Indicators } & \multicolumn{4}{|c|}{ Year } \\
\cline { 2 - 5 } & $\mathbf{1 . 0 1 . 2 0 1 6}$ & $\mathbf{1 . 0 1 . 2 0 1 7}$ & $\mathbf{1 . 0 1 . 2 0 1 8}$ & $\mathbf{1 . 0 1 . 2 0 1 9}$ \\
\hline GDP & 1979458 & 2383182 & 2982920 & 3558706 \\
\hline $\begin{array}{c}\text { Loans granted by banks to the } \\
\text { Ukrainian economy, all together }\end{array}$ & 1009768 & 1005923 & 1036745 & 1118618 \\
\hline $\begin{array}{c}\text { Loans given to economic } \\
\text { management entities }\end{array}$ & 830632 & 847092 & 864412 & 919054 \\
\hline $\begin{array}{c}\text { Share of loans to economic } \\
\text { entities, \% }\end{array}$ & 82,2 & 84,2 & 83,3 & 82,1 \\
\hline Loans given to individuals & 175711 & 157385 & 170774 & 196634 \\
\hline Loans given to public authorities & 3360 & 1427 & 1517 & 2865 \\
\hline $\begin{array}{c}\text { Loans to non-bank financial } \\
\text { institutions }\end{array}$ & 65 & 20 & 42 & 66 \\
\hline $\begin{array}{c}\text { Share of bank credit investments } \\
\text { in GDP, \% }\end{array}$ & 82,2 & 42,2 & 34,7 & 31,2 \\
\hline $\begin{array}{c}\text { Share of loans to individuals in } \\
\text { GDP, \% }\end{array}$ & 8,8 & 6,6 & 5,7 & 5,5 \\
\hline
\end{tabular}

A loan portfolio is a totality of all bank loans structured according to certain parameters in accordance with the tasks set by the bank's credit policy. Profitability and risk are the main parameters of managing a bank's credit portfolio. The ratio of these indicators determines the effectiveness of bank lending activities.

The main aim of the process of managing a bank's loan portfolio is to maximize profitability at an acceptable level of risk.

It should be noted, that the loan portfolio is not just a passively formed set of loans, but the result of active, purposeful actions of a dynamically developing bank, a purely managerial balance between different types of loans. A bank's loan portfolio should be seen as an embodiment of the bank's credit policy, which is an integral part of its overall development strategy [12].

Analyzing the credit portfolio of domestic banks, it can be seen that during 2015-2018 its volume does not vary significantly and in 2018 amounts to UAH 1042798 million. Interest income at the end of the year was $-8.6 \%$. As for the profitability of the loan portfolio, it is declining during 2015-2018.

Thus, the amount of the bank's income from credit operations is generally influenced by two main factors: portfolio scope and the level of interest pace on loans, the latter being a general indicator, since the level of interest rate indirectly takes into account such factors as the duration of the loan, method of calculation and method of payment of interest, loan security. In addition, the level of profitability of a bank's loan portfolio depends on a number 
of economic factors: market interest rate, volume and structure of the loan portfolio, conditions of competition in the banking market, own ability of the bank to choose directions and lending facilities, etc. [12].

Table 2

Profitability of loan portfolio of domestic banks for 2015-2018. [11]

\begin{tabular}{|l|c|c|c|c|}
\hline \multirow{2}{*}{ Indicators } & \multicolumn{3}{|c|}{ Yearly information as of January 1 } \\
\cline { 2 - 5 } & $\mathbf{2 0 1 5}$ & $\mathbf{2 0 1 6}$ & $\mathbf{2 0 1 7}$ & $\mathbf{2 0 1 8}$ \\
\hline Loan portfolio mln.UAH & 1006358 & 1009768 & 1005923 & 1042798 \\
\hline Interest income mln.UAH & 151257 & 135145 & 135807 & 124009 \\
\hline $\begin{array}{l}\text { Interest income growth } \\
\text { pace, \% }\end{array}$ & 16,4 & $-10,6$ & 0,4 & $-8,6$ \\
\hline $\begin{array}{l}\text { Credit portfolio } \\
\text { profitability,\% }\end{array}$ & 15,0 & 13,3 & 13,5 & 11,8 \\
\hline
\end{tabular}

In domestic banking practice, the unification is carried out through the methodology of forming a credit risk reserve, developed by the National Bank of Ukraine. Indeed, the reserve formation method provides an explanation of the magnitude of the possible losses for each individual loan, and the sum of the amounts thus found (probable losses on all credit operations of the bank) forms a reserve, so it becomes apparent that the economic content of the reserve is an indicator of aggregate risk credit portfolio of the bank [14]. Thus, the reserve formed by the bank allows to determine the risk of the loan portfolio, which is calculated as the pace of the calculated value of the reserve for credit operations of the bank to the amount of the loan portfolio.

Figure 1 shows that the banks' credit portfolio for 2015-2018 grew (by 14.4\% with annual growth rate of $10.4 \%, 0.3 \%,-0.4 \%$ and $3.7 \%$, respectively) ), which is a positive phenomenon for banks, since credit operations are the main source of bank revenue. During the period under review, the volume of such reserves increased by 4.2 times. It should be noted that the share of reserves in the credit portfolio of banks in 2018 was $49.6 \%$ (for comparison, in 2015 it was $20.40 \%$ ).

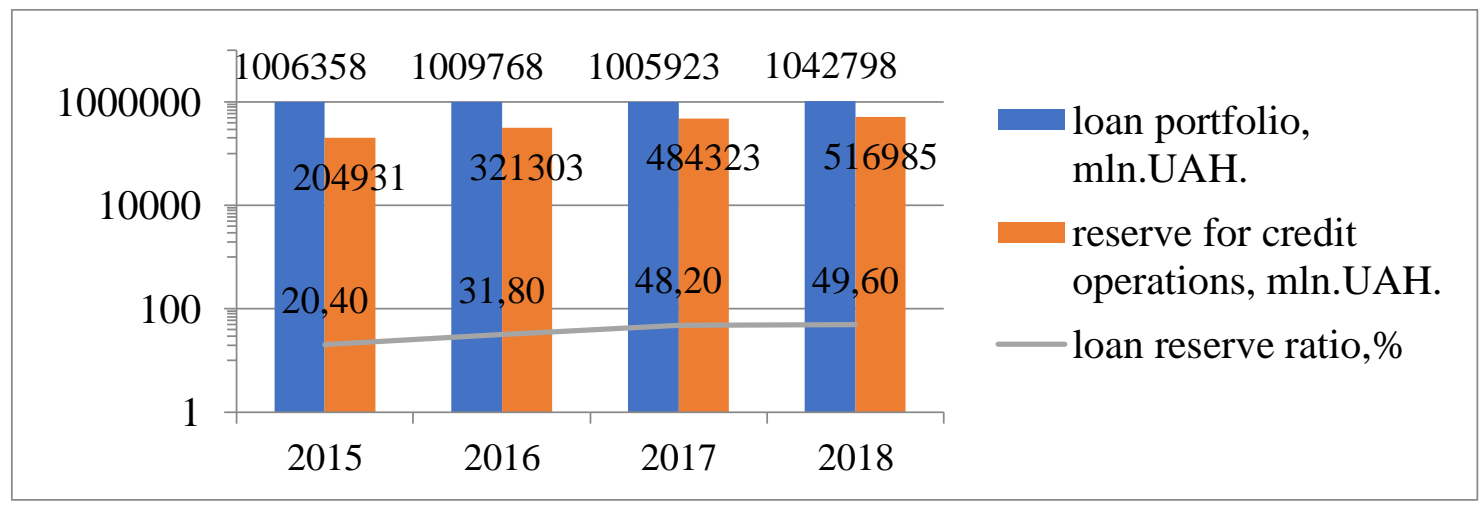

Figure 1 - The risk in credit portfolio of domestic banks for 1.01.2015-2018 years. [11]

Therefore, having done the analysis of credit activity of domestic banks during 20152018, we can say that there is a negative tendency of deterioration of their main indicators, which worsens the overall economic situation of our country. In general, it was influenced by factors such as: reduction of the resource base; deterioration of borrowers' creditworthiness 
and a high level of uncertainty about further economic development, which, in turn, forces banking institutions to treat the financial position of potential borrowers more carefully or suspend lending for some time.

In light of the current crisis in the financial sphere and the complication of banking products, it implies the creation and functioning of an effective risk management system in domestic banks. The Bank's credit risk management is performed at two levels according to the reasons for its occurrence - at the level of each individual loan and at the level of the credit portfolio as a whole. Banking institutions use different methods of managing individual credit risk: analysis of the borrower's creditworthiness; credit analysis and evaluation; structuring of loans; documentation of credit operations; control over the loan and collateral.

Different methods are used to assess credit risk. Some of them are built using large amounts of information about previous lending experience; others are reduced to analyzing information and comparing it with a number of specially defined criteria. For example, recently JSC JSB "Ukrgasbank" uses methods of estimating the quality of potential borrowers with the help of various statistical models in order to develop standard approaches for determining the objective characteristics of borrowers, finding numerical criteria for dividing future clients based on the materials they provide on reliable and unreliable bankruptcy risk takers and those for whom bankruptcy risk is unlikely [15]. An example of this model would be the Zeta model, developed by a group of American economists and used by banks in credit analysis, and the bank's credit risk mitigation model. [16]. The scoring method allows you to conduct a rapid analysis of the loan application in the presence of the client. At JSC JSB "Ukrgasbank", having applied for a loan and completing a special application form, it can receive a reply about the possibility of granting a loan within a few minutes.

Current banking practices have created different systems of precautionary measures to mitigate the impact of credit risk. One of such warning systems in PJSC JSB "Ukrgasbank" is insurance, which manifests itself through self-insurance (formation and use of a reserve for possible losses on credit operations) and the method of external insurance that occurs with the participation of insurance companies [17].

Self-insurance is based on the formation and use of a reserve for possible losses on credit operations [18]. The method of self-insurance is to accumulate a certain amount of financial resources, which, if necessary, are used to cover possible losses on credit operations.

The crux of external risk insurance is that the debter is ready to dismiss some of the income in order to avoid the risk to pay to reduce the risk level to minimum.

The study proved that the most common method of self-insurance is JSC JSB "Ukrgasbank". However, the application of this method is associated with the possibility of significant losses to the bank, if it focuses on its activities on the same type of credit operations, as well as deteriorating financial condition of borrowers.

We think that commercial bank policy is the bank's strategy and tactics for attracting funds and directing financial resources to lending to customers of the borrower bank based on the principles of turnover; urgency; differentiation; security; payments.

Each bank defines its own policy, taking into account the whole set of risks, both internal and external, which it burdens and which affect the effectiveness of its activities, including the attitude of the bank's management to risk [19].

It should be emphasized that the policy is the basis of the risk strategy in the bank's activity and can be aggressive or traditional (classic). In particular, credit policy, as the basis of the credit management process, sets priorities in the process of developing credit relations on the one hand, and the functioning of the credit mechanism on the other. In general, credit policy, in the context of the strategy, includes the priorities, principles and goals of an 
individual bank in the credit market, and in terms of tactics - the financial and other tools used by a commercial bank to achieve its goals in the implementation of credit agreements, rules for their implementation, rules for the organization of credit process, as well as to achieve the set goals each organization uses its own concept of activity.

Since the main purpose of a commercial bank is to make a profit, and credit operations occupy a significant place in the bank's activities in general, it is necessary to create all conditions for maximum and full involvement of all segments of the population and all economic entities in the credit process [20].

However, lending is a rather risky activity, since there is a risk of a loan default, which in turn already eliminates the profit from the transaction, so banks need to carefully weigh all the risks and act on the bank's lending strategy.

In accordance with the strategy, goal achievement can be achieved through the use of a mechanism that includes the following elements:

- introduction of full types of banking products for both individuals and legal entities;

- expansion of financial ratios for the analysis of the client base;

- implementation of an effective marketing policy.

- the use of a model of limiting the amount of acceptable credit risk for a debtor in a bank.

To continue the study, we will indicate that the most important task of banking risk management at PJSC JSB "Ukrgasbank" is to create conditions that would provide the optimal balance between profit, risk and liquidity. Today, one of the newest methodological concepts of strategic management of the bank is the methodology of developing "strategic maps" of the bank's development. We believe that the use of this methodology in the work of PJSC JSB "Ukrgasbank" will allow to ensure the implementation of a balanced system of management effectiveness indicators at the same time as the development and implementation of the Bank's strategy.

Strategic maps can be created at any level of management, and every level of management of PJSC JSB "Ukrgasbank" will have an opportunity to see its place on the common strategic map.

In the context of a system of balanced economic indicators, a bank should be examined and evaluated from four positions:

- the bank's financial position (profitability, profitability), the level of riskiness of banking operations, where the key indicators for the development of banks are such risk indicators as aggregate risk and the level of coverage of expected losses created by the reserves in the market (goals of the financial component - economic results of a successful strategy);

- bank behavior in the market (number of clients, market share in geographical and product perspectives), when formulating a client component of a strategic map, managers determine the target segments of the consumer market in which this business unit competes and performance indicators from the point of view of clients;

- efficiency of internal business processes. Responsible for two vital components of the strategy: developing and delivering value proposition to the client; process improvement and cost reduction as a means of increasing productivity in the financial component;

- level of development of human resources of the bank: reflects those intangible assets that are most important for the strategy [21].

Thus, risk management at PJSC JSB "Ukrgasbank" should provide for objective determination of its current and desirable status, coordinated management of the bank's 
financial resources, choice of such management decisions that contributed to avoiding risks or minimizing their negative consequences.

The objectives of risk management at PJSC JSB "Ukrgasbank" are the financial results of a successful strategy, namely the improvement of financial stability of a banking institution.

In the continuation of the study, we note that the competitive advantages of banks in foreign countries is the presence of effective marketing strategies, which ultimately provides high performance of such banks, high level of financial stability and the ability to manage banking risks.

Traditionally, banks' product policies are geared to delivering innovative services such as: online acquiring, multicurrency deposits, new deposit solutions, issuance of "privileged" plastic cards, consulting services (for example, tax, legal advising, developing tax-minimizing recommendations and tax planning).

Today, JSC JSB Ukrgasbank has some factors that limit marketing effectiveness, such as:

-low marketing expenditures (marketing costs less than $2 \%$ of total expenditures in banks, while consumer goods companies - 15\%);

-the traditional organizational structure of banks prevents them from implementing a customer-oriented marketing strategy.

Continuing the study, it should be noted that banking institutions should develop individual organizational and managerial strategies for finding the means of meeting the needs of both bank clients and their own interests.

By creating a system of effective management of money, loans, interest, currencies, calculations and taking into account the peculiarities of the marketing environment and the existing market conditions of the loan capital, the bank improves its performance, which in turn strengthens the financial stability of the bank as a whole.

The basic idea of developing an organizational and management strategy is to identify the needs, demands and preferences of consumers and, in this regard, to identify market segments that can find a niche for the implementation of new banking products and services in competition with other banks.

As it was mentioned earlier, the main purpose of credit risk assessment is to identify the possible level of risk and to identify factors that affect the credit risk of the bank, including the solvency of the debtor. To analyze the solvency of the debtor, the bank calculates and analyzes such indicators as the coefficients of current, instantaneous and total liquidity. The bank then analyzes the borrower's financial soundness indicators to make a decision on granting a loan. Such indicators reflect the structure of the capital of the enterprise, the share of its own and borrowed resources of the enterprise make it possible to find out the solvency of the enterprise. Further, these indicators are used by the bank to calculate the integral factor of a multifactor model, which looks like:

$$
Z=a_{1} K_{1}+a_{2} K_{2}+a_{3} K_{3}+a_{4} K_{4}+a_{5} K_{5}+a_{n} K_{n}-a_{0},
$$

where $\mathrm{Z}$ is the basic integral index of the financial position of the debtor - legal entity;

$K_{1}, K_{2} \ldots K_{n}$ are the financial ratios calculated on the basis of the debtor's financial accountability;

$\mathrm{a}_{1}, \mathrm{a}_{2} \ldots \mathrm{a}_{\mathrm{n}}$ are parameters that are determined by taking into account the weight and the bit rate of the financial coefficients on the basis of the financial statements of the debtor legal entities; the value of the weight parameter is not identical to the specific weight of the corresponding financial coefficient in the structures of the integral index;

$\mathrm{a}_{0}$ is a free member of the discriminant model. 
Based on the characteristics of the debtor's social and financial situation, the bank concludes on what financial position the debtor has in order to settle his or her own obligations to the bank. Then, the amount of debt to be paid by the client for the duration of the loan agreement is established by the bank's institutions (principal + interest on using the loan).

If the amount paid by the debtor is insufficient to cover the determined monthly loan amount and accrued interest, the interest on the loan will be repaid first and the amount owed will be aggravated.

After assessing the debtor's creditworthiness, the bank chooses a credit risk management strategy. There are three variants of the given strategy (Figure 2).

Most frequently, the bank chooses credit risk minimization instruments. Risk monitoring is performed primarily on the basis of the quarterly or monthly control of the borrower by the credit subdivision. In the course of monitoring, the unit updates the information about the borrower, draws its own conclusion on the results of monitoring, as a rule, with the account of information of the economic security, economic information service. Having analyzed the activities of banking institutions and the process of minimizing credit risk, we consider it expedient to use the methods of limitation and the acceptance of collateral in banking management, since these methods are most effective in lending to clients.

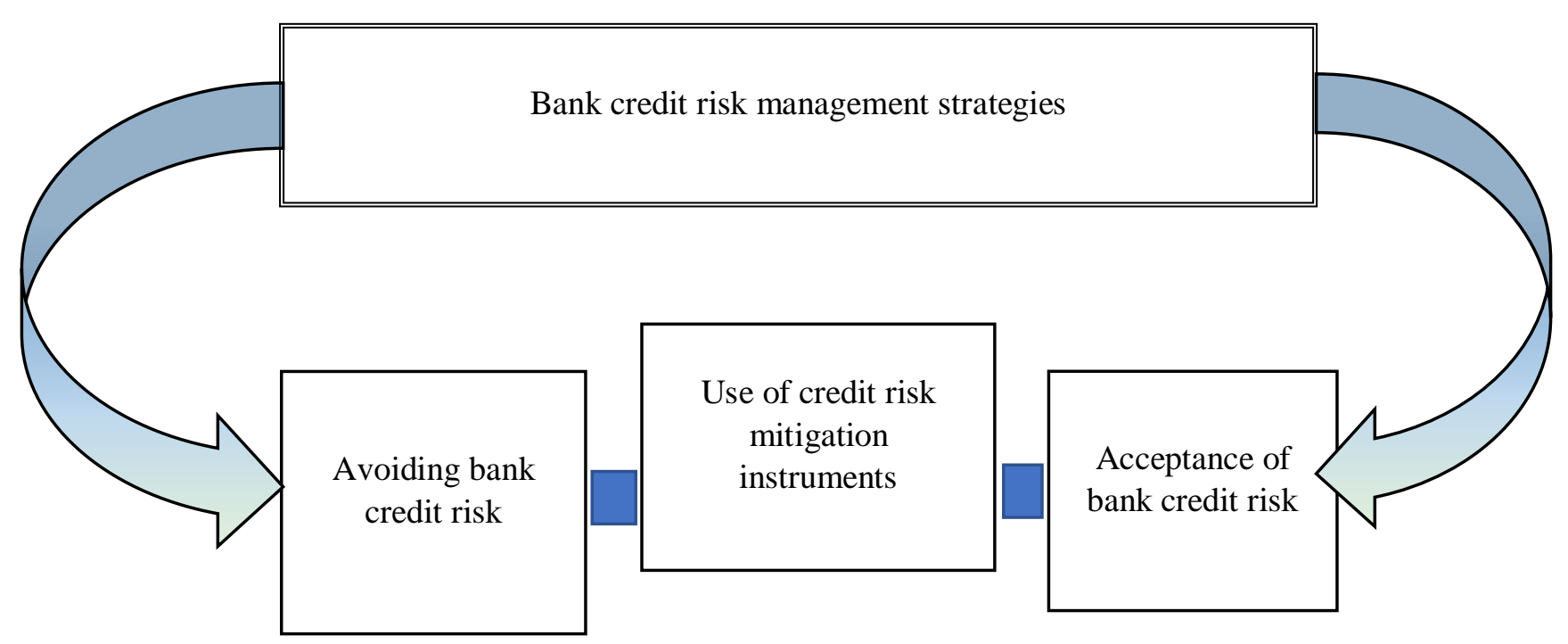

Figure 2 - Variants of bank credit risk management strategies

Limitation, as a method of managing credit risk, is to set the maximum permissible amount of loans provided, which allows to limit the risk. Commercial banks use one of these forms of credit line opening credit facility, which is legally formalized by the bank's obligation to the borrower to provide loans within the stipulated limit within the stipulated term. At the same time, the bank, by granting a loan, is forced to control the observance of mandatory economic norms for regulating the activity of commercial banks. The shortcomings indicate that the limit, as one of the most important tools for managing a bank's individual credit risk, needs improvement, and the formalization of the approach to limiting the amount of individual credit risk taken by the bank and the development of an appropriate model are extremely relevant. 
As a rule, the credit risk limit is calculated as a fraction of the cost of securing a specific asset of the debtor:

where:

$$
\mathrm{Lk}=\mathrm{kl} * \mathrm{PV}
$$

$\mathrm{Kl}$ is the limiting rate;

$\mathrm{PV}$ is the present value of a particular debtor asset.

If the security is a security deposit, the $50 \%$ limit ratio is generally used; if the capital (the balance of assets after settlement of all liabilities) - 10\% ratio; if total assets, the limiting factor is $1-3 \%$

We have calculated a limit based on the credit data of a client of PJSC JSB "Ukrgasbank". The field of activity of this debtor is construction. According to the submitted documents, the legal entity applied for a loan worth UAH 1 million for the purchase of equipment.

Step by step, our actions were as follows:

1. Determined the base limit for this debtor by the formula:

$\mathrm{IBL}=2050 * 24 *(91.2 / 2050)=\mathrm{UAH} 2188.8$ thousand

2. The indicator of effective activity was calculated:

$\mathrm{Kb}=(1 / 2-1) *(27900 / 27752) *(28141 / 27900)=1.013$;

$\mathrm{Kvk}=(1 / 2-1) *(6245 / 6197) *(6252 / 6245)=1.008$

$\mathrm{Ia}=1.008 * 1.013=1.021$.

3. The value of the solvency index was calculated, for which the integral index for the construction sphere was determined:

$\mathrm{Q}=0,02 * 1,2+1,3 * 0,62+0,03 * 0,89+0,61 *(-0,001)+0,75 * 0,035+2,5 *(-0,012)-0,2=0,66$

To calculate the integral indicator, we will use the following coefficients: the coefficient of financial independence, the ratio of coverage of non-current assets with equity, the coefficient of turnover of payables, the coefficient of profitability of sales of financial results before tax, the coefficient of profitability of financial performance.

4. Determined the class of the debtor according to the table "Debtor classes", which is equal to Ip $=1$.

5. The rate of return was calculated. For this metric, we use metrics such as total revenue and total spend. So let's calculate this indicator: Yiw $=(2050 / 1077)-1=0.90$

As we can see, this figure is 0.90 , which means covering its expenses by $90 \%$, the bank assumes a risk of $10 \%$ of the principal amount of debt. Having received all the components for the calculation, they calculated the credit risk limit for this enterprise, which exceeds UAH 2 million.

Limit $=2188.8 \times 1,021 \times 1 \times 0.90=2011.3$ (UAH thousand)

Therefore, we believe that it is appropriate to take into account the rate of return for better management of a bank's credit risks. But this method of calculating the limit is used for many loans. For larger loans, a more accurate method of calculating the credit risk limit should be used. With the extension of the loan term, the rate of limitation decreases, which is associated with an increase in the uncertainty of the value of the pledge in the distant future. As the volatility of the collateral value increases, the uncertainty of its value over time also increases, so the rate of limitation decreases. The higher the credit rating is, the lower the credit limit. If the level of trust decreases, the lowest collateral value increases, the rate of limitation increases.

Conclusion. The essence of the notion bank risk is widely shown in the literature, but after analysis of the authors thoughts, we have determine understanding of credit risk, as the probable risk for income and capital, which is manifested by the inability of the side to fulfill 
the terms of any financial agreement with the bank or otherwise fulfill its obligations. Analysis of credit activity of domestic banks during 2015-2018 has proved that there is a negative tendency of deterioration of their main indicators, which led to the deterioration of the overall economic situation in our country. PJSC JSB "Ukrgasbank", which was the subject of our research, uses different methods of managing individual credit risk: analysis of the debtor's creditworthiness; credit analysis and evaluation; structuring of loans; control over the loan and collateral. Current banking practices have created different systems of precautionary measures to mitigate the impact of credit risk. One of such warning system in the bank's research is insurance, which manifests itself through self-insurance and the method of external insurance. In addition, we believe that the implementation of marketing and management tools can provide opportunities to ensure effective management of banking risks. Having provided an assessment of the activities of banking institutions and the process of credit risk minimization in PJSC JSB "Ukrgasbank", we propose to use in banking management methods of limitation and acceptance of collateral, as these methods are most effective in clients lending.

\section{REFERENCES}

1. Про банки і банківську діяльність: Закон України від 7 грудня 2000 р., №2121.111; №661-VI (661-17) від 12.12.2008 р. // Вісник Верховної Ради - 2009. - №15. - С. 190.

2. Еш С. Фінансовий ринок [Текст]: навч. посібник / С. Еш. - К.: Центр навчальної літератури, 2009. - 528 с.

3. Гроші та кредит [Текст]: навч. посіб. / А. Демківський - К.: Дакор, 2005. - 528 с.

4. Фінансовий ринок [Текст] : підручник / В. Шелудько. - К. : Знання, 2008. - 535 с.

5. Карпінський Б. Фінанси: термінологічний словник [Текст]: навч. посібн. / Б. Карпінський, Т. Шира. - К.: Професіонал, 2008. - 608 с.

6. Никитіна К. Кредитний ризик: генезис і дефініція [Текст] / К. Никитіна // Торгівля і ринок України : зб. наук. праць. - Донецьк, 2009. - Т.3. - С. 231-239

7. Парасій-Вергуненко I. Аналіз банківської діяльності [Текст] : навч.-метод. посібник./ І. Парасій-Вергуненко. - К. : КНЕУ, 2003. - 347 с.

8. Про затвердження Положення про визначення банками України розміру кредитного ризику за активними банківськими операціями: Постанова Правління Національного банку України № 351 від 30 червня 2016 року [Електронний ресурс]. Режим доступу: https://www.bank.gov.ua/document/download?docId=33378802

9. Документ Базельського комітету 3 питань банківського нагляду «Надійна практика управління та нагляду за операційним ризиком». - Матеріали Базельського комітету з банківського нагляду, лютий 2003 р. / [Електронний ресурс]. - Режим доступу: http://wwwbis.org/bcbs/index.htm

10. Кредитна діяльність банків України: проблеми та перспективи розвитку: монографія / За ред. В.В. Коваленко. - Одеса: Видавництво «Атлант», 2015. - 217 с.

11. Національний Банк України [Електронний ресурс]. - Режим доступу: https://bank.gov.ua/control/uk/publish/article?art_id=34661442

12. Волкова Н.I. Тенденції та особливості кредитної діяльності вітчизняних банків на сучасному етапі розвитку економіки / Н.I. Волкова, А.О. Кункель // Економіка і організація управління. - №1 929). - 2018. - С.52

13. Рогожнікова Н.В. Основні тенденції банківського кредитування в сучасних умовах фінансово-економічної кризи / Н.В. Рогожнікова // Фінансовий простір. №3(19). - 2015. - С. 72 
14. Національне рейтингове агентство «Рюрік». Аналітичний огляд БСУ за 2016 рік: [Електронний ресурс]. - Режим доступу: http://rurik.com.ua/documents/research/bank system 4 kv 2016.pdf

15. Бобиль В.В. Антикризове управління банківськими ризиками: Монографія / В.В. Бобиль. - Дніпропетровськ: видавництво «Свідлер А.Л.», 2012. - 270 с.

16. Бондар А. В. Удосконалення систем управління банківськими ризиками [Електронний ресурс] / А. В. Бондар // Управління розвитком. - 2014. - № 9. - С. 132133. - Режим доступу: http://nbuv.gov.ua/UJRN/Uproz_2014_9_57

17. Войтов С. В. Аналіз моделей оцінки кредитного ризику позичальника на основі визначення ймовірності дефолту. Проблеми їх імплементації в умовах банківської системи України [Електронний ресурс] / С. В. Войтов // Молодий вчений. - 2015. - № 9(1). - С. 55-59. - Режим доступу: http://nbuv.gov.ua/UJRN/molv 2015 9(1) 14

18. Гальчинський А. Теорія грошей: навч-метод.посібник / А. Гальчинський // Міжнародний фонд «Відродження» - К.: Основи, 2013. $413 \mathrm{c}$.

19. Гострик О. М. Визначення допустимого кредитного ризику комерційного банка 3 використанням методу системної динаміки [Електронний ресурс] / О. М. Гострик, О. А. Степаненко // Науковий вісник Ужгородського національного університету. Серія : Міжнародні економічні відносини та світове господарство. - 2016. - Вип. 6(3). - С. 6063. - Режим доступу: http://nbuv.gov.ua/UJRN/Nvuumevcg_2016_6(3)_15

20. Грошово-кредитна діяльність банків: навч. посіб. / М.П. Денисенко, В.Г. Кабанов, Л.М. Худолій. - К.: Вид-во Європ. ун-ту, 2016. - 339 с.

21. Дзюблюк О.В., Прийдун Л.М. Кредитний ризик і ефективність діяльності банку: монографія / О.В. Дзюблюк, Л.М. Прийдун. - Тернопіль: ФОП Паляниця В.А., 2015. 295 c. 